\title{
NAKED RAKU RESEARCHES
}

Şirin Koçak

Dr., Uşak University, Faculty of Fine Arts, Department of Ceramics, Uşak, Turkey

Recebido em 30/08/2018

Aprovado em 27/11/2018 
Raku has been one of the favourite firing techniques since it allows low-firing and offers a wide range of colour options on glaze. Ceramicists' researches in an effort to create different and alluring surfaces on a ceramic body have led to the enrichment of this technique with some variations. As a result of this quest, ceramic artists began experimenting with decorative effects on a ceramic body without using glaze in 1980s. Raku firing technique without using glaze, called Naked Raku in foreign sources, has twobasictypes, one-step nakedrakuandtwo-step nakedraku. Inone step nakedrakutechnique a thick slip is appliedtobisquefiredceramicpiecesand it is firedwhile it is wetandthenreduced. In two step nake drakuthin/ thick slip is applied and covered withlow- fire glazeandreduced. The aim of this study is to examine the development process of naked raku and giving examples from artist's own experiences. The study includes today's raku production process, the characteristics of clay, slip and glaze used in this process, and the firing technique.

Palavras-Chave: Ceramic, Raku, Surface Without Glaze, Slip, Naked Raku.

$\mathrm{R}$ aku's history that started from the 16th century up until today continues with individual experiments and applications and the curiosity the artists have for raku firing and with the forming and development of new firing styles. In the 1980's as an outcome of the ceramic artists' personal trials without using glazes, the development of the firing technique which is used to obtain a decorative surface known as 'naked raku' started to be developed.

The main feature that separates 'naked raku' from raku is that there is no shining/matte glaze layer that covers the body surface as there is in raku.Along with the similarities in firing steps, the fact that naked raku has different qualities of surface than raku in the end product has been influential in the preference of ceramists' for this method whom has interest in surfaces without glaze.

"The oldest known pioneer and applier of 'naked raku' is Jerry Caplan. The technique in which Caplan patterned the template method and realized raku firing is actually the technique we define as 'the one step naked raku' today. In 1986, Kate and Will Jacobson developed their authentic two stage 'naked raku' technique using slip and glaze, in addition, in 1996 Charlie and Linda Riggs, developed their own one step 'naked raku' technique using only slip." Following these artists, other artists also independently contributed to the advancement of the technique with their authentic adaptations. The 
artists who developed and pioneered in popularization of the 'naked raku' technique can be listed as follows; Wally Asselberghs (Belgium), Margot Spiegel Kramer (Netherlands), Gordon Hutchens (Canada), David Roberts (UK), Simcha Even- Chen (Israel). Other ceramists who study the subject are Tim Andrews, Alistair Danhieux, Janine Parent, Emma Johnstone, Allyson May, Jan Lee.

\section{What is 'NAKED RAKU'}

$\mathrm{N}$ aked Raku is a technique whereby decorative surfaces are formed with the application of slip and glaze in the process of raku firing on a biscuit fired ceramic product. Ceramic product is taken out of the kiln and left in reduced atmosphere in the range of $850-900{ }^{\circ} \mathrm{C}$ or 900- $980^{\circ} \mathrm{C}$, in a closed container. The layer of glaze and slip that covers the ceramic surface, by partly inhibiting the sooting of the smoke emerging in the process of reduction on the texture, forms decorative effects on the surface, ranging from white to gray and black according to the colour of the texture. 'Naked raku' is named after this process of peeling and detachment of the applied slip and glaze layer from the ceramic surface like the shell of an egg and is also known as 'resist slip raku'.

E. Şölenay defines the firing method of 'naked raku' as follows " ...it is done in a way that is different than regular raku firing, glaze is not used in the products and because of the reduction made on the surface positive, negative colour and texture values are obtained. In this application, there is need for slip and glaze. The slip used should show refractive quality and it should be easily detachable from the ceramic surface it is applied on after the process of firing." ${ }^{2}$

The slip prepared with certain recipes for this method is called resist slip; the process of firing done with sole usage of slip is named resist slip raku or 'one step naked raku' *; whereas the process of firing where slip and glaze layers are applied successively is named 'two step naked raku' ${ }^{* *}$. 


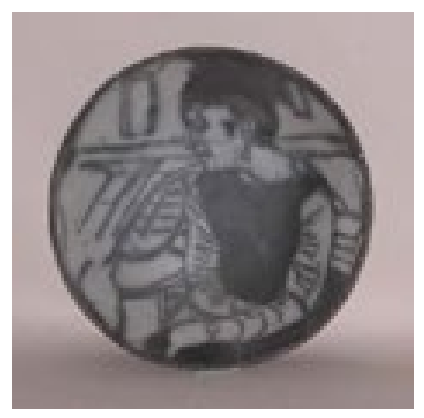

Image 1: "Punk Girl”, Jerry Caplan

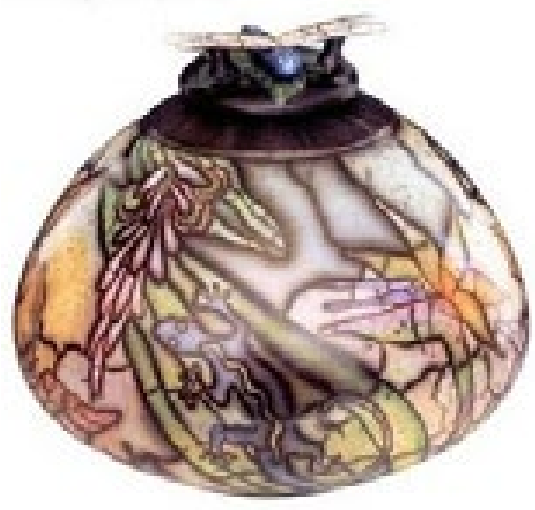

Image 2:" Aunt's Garden", Kate and Will Jacobson

\section{ONE STEP 'NAKED RAKU' AND ITS SLIP}

B asically, it is the firing of a biscuit fired ceramic product in reduction atmosphere, with a thick slip applied. In one step 'naked raku', only slip layer is applied on the piece before the firing is done. The piece is placed in the kiln and fired while it is wet. This slip which is peeled from the surface like a shell is obtained from diluted clay which is generally used for shaping.

It is necessary to apply the slip thickly in order to speed up the cracking of the slip while it dries in the oven. Since the slip is easily broken, sometimes it can be shed while in the oven during the firing. For this reason, the steps of the application must be carried out with care.

The original recipe used by ceramist couple Charlie and Linda Riggs in their one step 'naked raku' firing is composed of the kaolin called EPK ${ }^{*}$, fire clay and aluminium oxide hydrate $(\mathrm{Al}(\mathrm{OH}) 3)$. 
The slip prescription used by Riggs in one step naked raku:

"Lincoln Fire Clay / Hawthorne Fire Clay 5 part

EPK Kaolin

Aluminium Oxide Hydrate $(\mathrm{Al}(\mathrm{OH}) 3$ )

3 part

2 part" 3

The slip which is defined as 'clay' or 'watered clay' by Charlie Riggs is of a very dense character. (See image 3 )

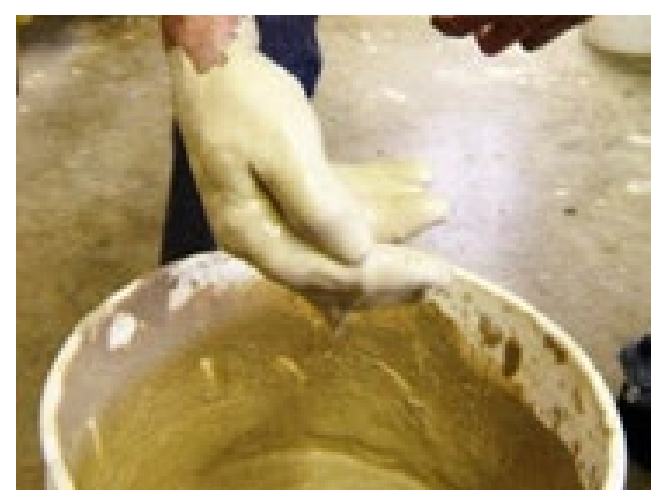

Image 3: Slip which is used by Charlie and Linda Riggs in one-step naked raku

Glaze is not applied on the slip in one step 'naked raku' firing technique. While the product is being fired, the slip contracts and cracks like drying of clay in the sun. The product is taken out of the kiln and placed in a metal container filled with newsprint and sawdust. This constitutes the atmosphere (reduction atmosphere ${ }^{\star}$ ) which will facilitate the sooting of smoke/carbon on the clay on the surface of the pot. Slip functions as a barrier and blocks the smoke. The regions on the surface of the product that contacts smoke, blackens. Surfaces that are of slip remain white. After the product is cooled, the slip is removed and its smooth patterns of black and white cracks emerge on the clay texture. (See image 4,5) 


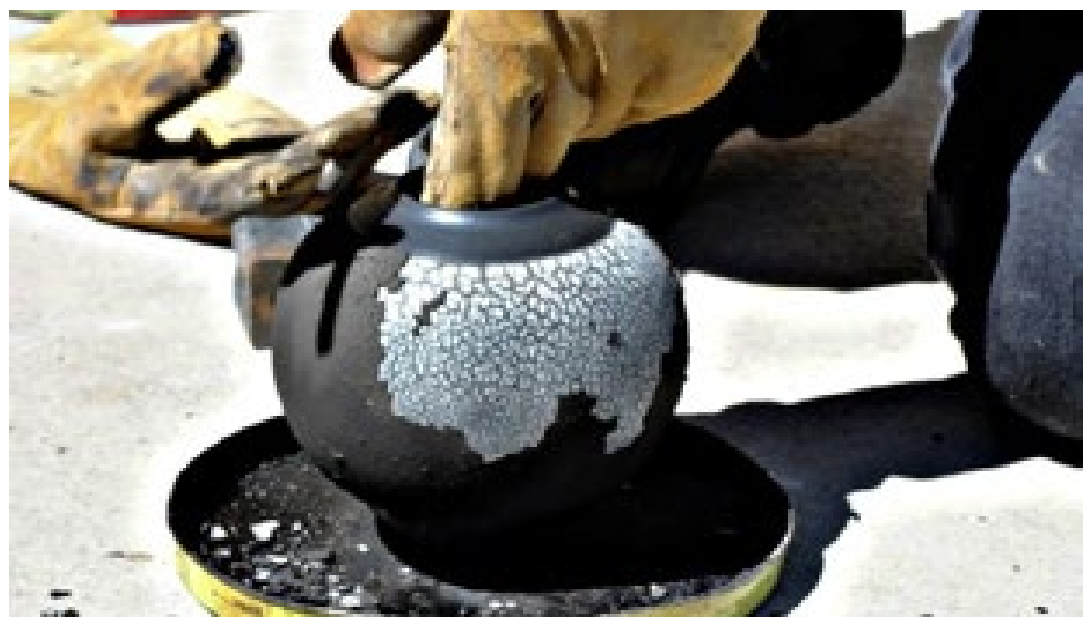

Image 4: Charlie and Linda Riggs's one-step naked raku, slip after reduction

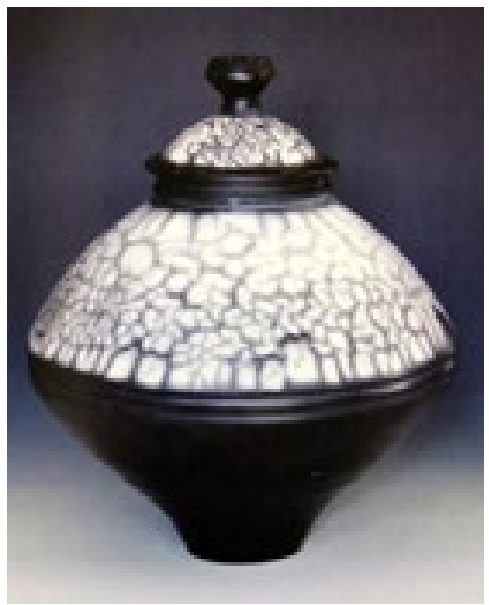

Image 5: Jar, terrasigillata, one-step naked raku, Linda and Charlie Riggs

Factors that influence the acquisition of a successful 'naked raku' product are as follows: the type of the clay which is used in shaping, constituents of the slip which is used in firing, how the firing is done, the care given in the removal of the piece from the oven in terms of how quick it is being removed and in the placement of the piece to the reduction box in terms of how well its physical condition is preserved. 


\section{Two step 'NAKED RAKU' and its specifications for slip and glaze}

$\mathrm{T}$ wo step 'naked raku' is the 'naked raku' firing of a biscuit fired ceramic piece on which a layer of specially prepared slip and a layer of glaze is applied successively. The feature that separates two step 'naked raku' method from one step 'unglaezed naked raku' method is the addition of glaze to the process. While only durable slip is used in one step 'naked raku', in two step 'naked raku' durable slip and glaze on slip is used. The contents of these slips and glazes consist of special blends developed by ceramists in their personal trials.

The slip used in two step 'naked raku' is thinner than the one used in one step 'naked raku'. This slip functions as a separating layer between the glaze and the texture. After the firing, before the piece is taken to the reduction section, the glaze begins cooling and cracking. If there is patterning done with sgrafitto or masking method on the piece, the glaze continues to crack on the surroundings of these patterns. In the reduction atmosphere, smoke soots on the slip and the surface of the piece by getting inside the cracks on the glaze. In order for the smoke to soot, the layer of slip should be thin.

The glaze that is used in two step 'naked raku' can be a transparent glaze with high expansion factor and low temperature. This glaze has a role of enduring smoke after the firing, during the reduction. The main purposes of the glaze being used are to keep the slip layer on the surface of the pot for a longer time, facilitating a more controlled reduction and assisting the distribution of black and white cracks on the entire surface.

All ceramists have glaze recipes they have developed on the light of their experiences. Of these glaze recipes "the most in-demand" transparent glaze prescription is the one prepared by Kate and Will Jacobson in 1985. This glaze is composed of \%65 Ferro Frit 3110 and \%35 Gertsleyborat." ${ }^{\prime}$

The slip which is as thin as an eggshell after the reduction is peeled easily when sprayed on with water and gets detached from the surface. By virtue of the shock created by cold water touching the hot glaze surface, the slip layer gets detached easily.

The steps of two step 'naked raku' application as actualized by Şirin Koçak are given below. 

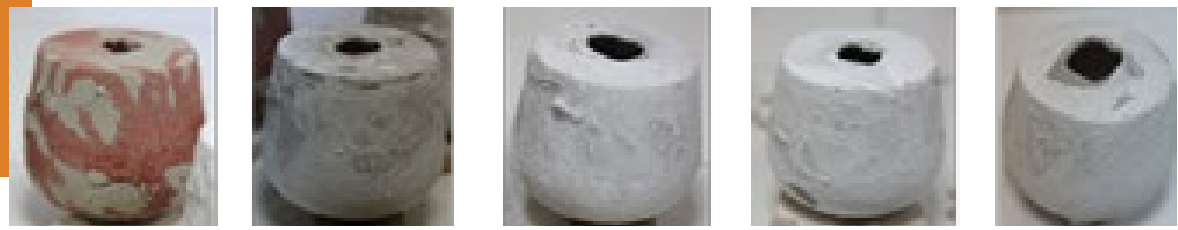

Slip and Glaze on slip application on ceramic pieces

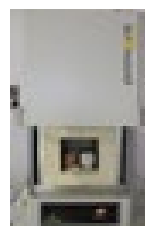

Pieces in the kiln
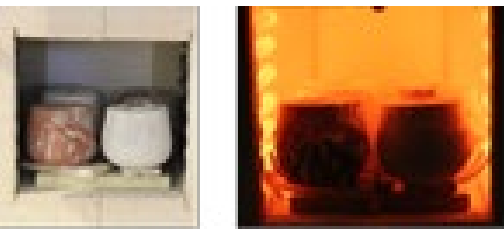

Opening the kiln at $980^{\circ} \mathrm{C}$
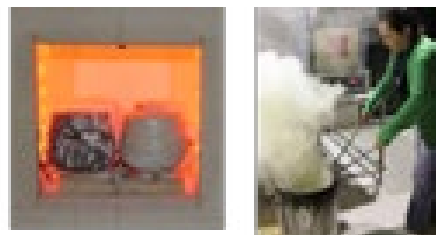

Reduction proccess
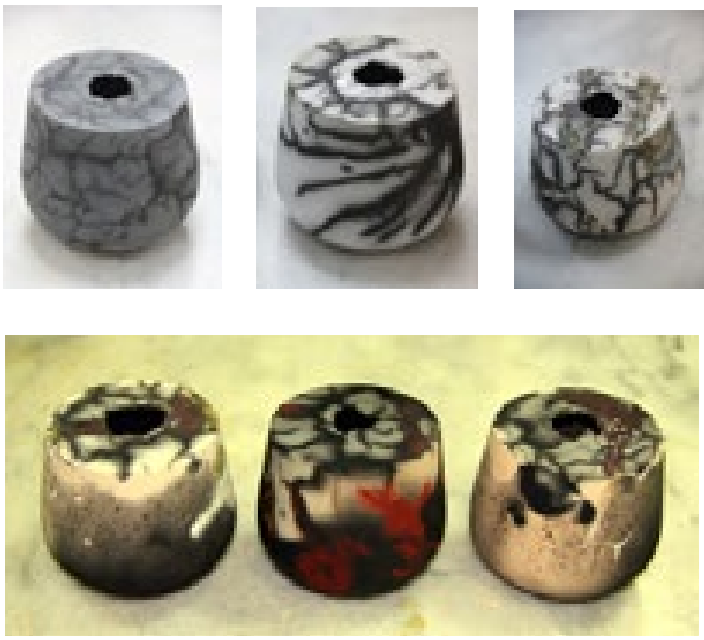

Results after firing

Image 6:The steps of two step 'naked raku' application, Şirin Koçak 
'Naked raku', yields better results when the product surface shaped before biscuit firing has an appearance of a smooth glossy stone. The process of obtaining this appearance begins with the decision of what type of clay will be used. The type of clay being used is the most important factor in obtaining this appearance. The clay should have a composition that will allow it to be smooth but at the same time durable to the thermal shock created in the raku firing process. Stoneware clays, porcelain clay, red pottery clay, paper clay are types of clay used by the artist in 'naked raku' applications.

\section{ARTISTS WHO USE 'NAKED RAKU'}

\section{TECHNIQUE AND EXAMPLES FROM THEIR WORK}

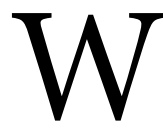

ally Asselberghs is a ceramist who applies 'naked raku' and is one of the best known ceramists in this field. Asselbergs "uses high temperature stoneware clay for his black and white objects. The clays he make are composed of \%55 clay, \%35 shamot and \%10 talk. Talk increases elasticity and endurance of the piece to shock during firing." Ashraf Hanna is one of the artists who exhibit unique works with two step 'raku' recipes and techniques he himself develops. In 'naked raku' applications, he does sgrafitto ploughings after slip and glaze applications to his hand shaped forms. After the works are cooled down he completes his works by applying the wax method.

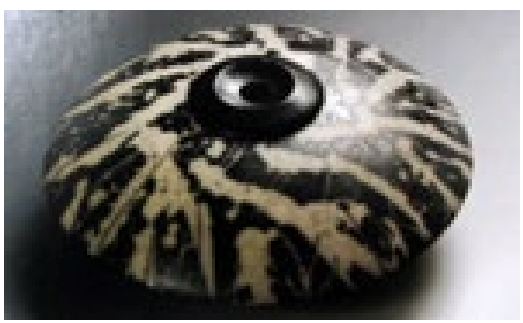

Image7: UCO ( Unidentified Ceramic Object), Wally Asselbergs

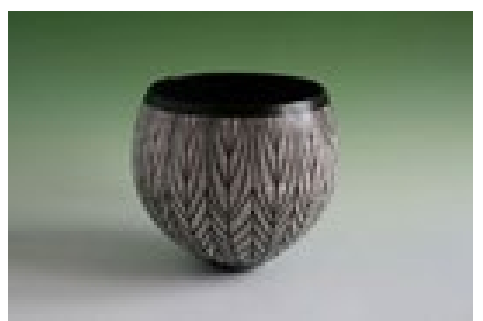

Image 8: Raku Bowl,h: $28 \mathrm{~cm}$., Ashraf Hanna 
Works of Simcha Even-Chen consist of division of the texture surface with lines into black and white areas and placement of intersecting lines in a connected fashion on the form. Simcha Even-Chen mixes stoneware and porcelain clays, shapes her works using plate method and laps her works after shaping. She applies a thin terra sigillata slip layer at skin stiffness. After reduction, once the works are cooled she proceeds to complete her works with a wax application.

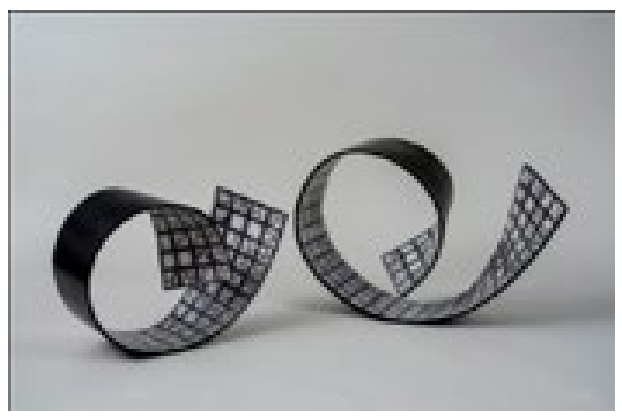

Image 9: "Spiralls ", Naked raku, 32x100x37 cm, Simcha Even-Chen

Roland Summer has been developing his own raku technique for many years and he uses special techniques in order to create the detailed and fragile surfaces in his pieces. He entirely uses terra sigillata slip in his works and "enriches, the terra sigillata slip he prepares by leaving it to rest for weeks, with raku firings"6. He applies the slip using one of the spraying, dipping or brushing methods on ceramic surface with skin stiffness dryness.

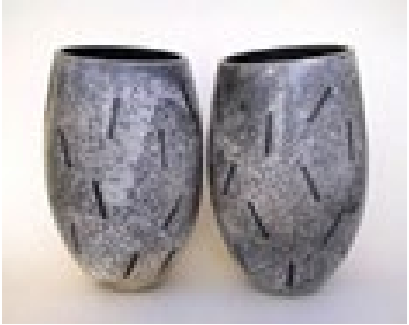

Image 10: "White pair" Vase, $\mathrm{h}: 43 \mathrm{~cm}$.

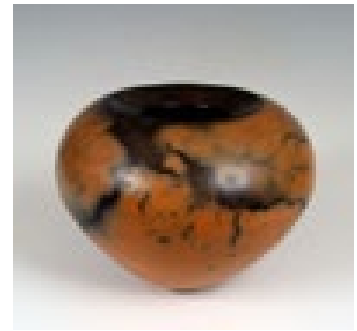

Image 11: Vase, Dia:27 cm Roland Summer 
Toygan Eren is one of the artists who exhibit numerous works using 'naked raku' technique in Turkey, he does two step 'naked raku' firing. Considering the specifications of the slips and glazes he uses, the artist prefers to do the firing at $930-940^{\circ} \mathrm{C}$, which is the range in which he gets the best results in raku firing. In raku firings, he prefers to reach $940^{\circ} \mathrm{C}$ in 4 hours in average. This way, it is possible for him to have a controlled development process for both the slip and the glaze.

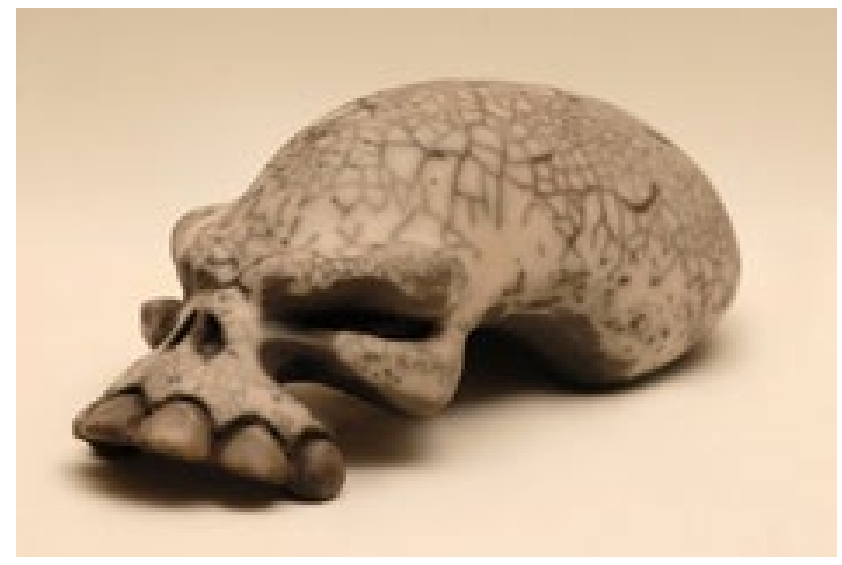

Image12: “Never”, Naked Raku, $930^{\circ} \mathrm{C}$, Toygan Eren

David Roberts is one of the most important ceramic artists of today, working in Europe. "He is acknowledged as the person who introduced raku firing technique and is internationally known. He pioneers the naked raku movement in USA and by doing this, transforms this technique into a form of contemporary art."' All of Roberts' works are applications of raku firing to pots shaped with the coiling method. Some parts of the surface are covered with slip and polished before firing. "Biscuit firings of the products are done at $1000^{\circ} \mathrm{C}$ and $1100^{\circ} \mathrm{C}$,raku firings are done at $850-950^{\circ} \mathrm{C}$ with a long reduction period and cooling phases." ${ }^{\prime}$ After the application, products are cleaned and dried; the end product is obtained with the usage of wax. 
Works of Simcha Even-Chen consist of division of the texture surface with lines into black and white areas and placement of intersecting lines in a connected fashion on the form. Simcha Even-Chen mixes stoneware and porcelain clays, shapes her works using plate method and laps her works after shaping. She applies a thin terra sigillata slip layer at skin stiffness. After reduction, once the works are cooled she proceeds to complete her works with a wax application.

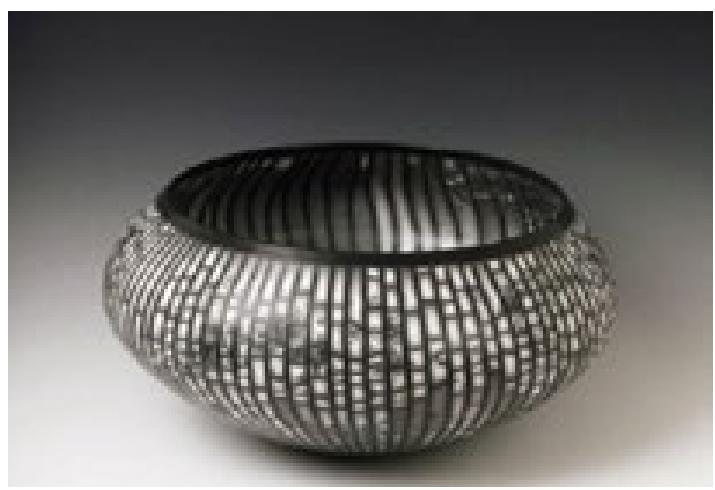

Image13: "Bowl”, David Roberts

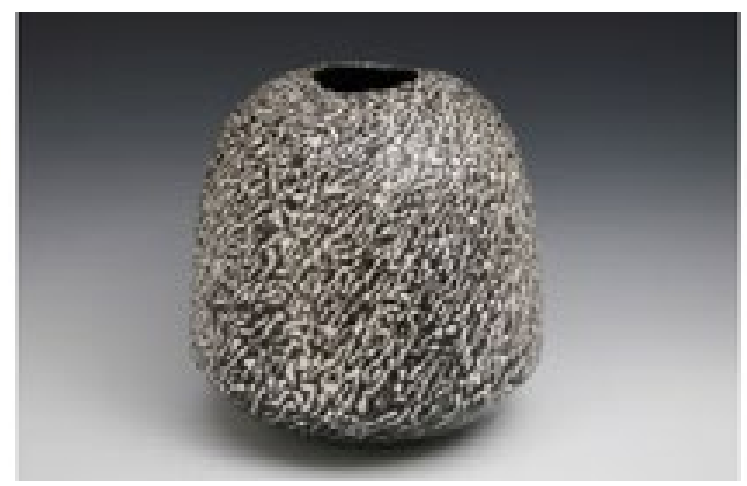

Image 14:"Vase", David Roberts 
Şirin Koçak does applications of one and two step naked raku firing, preparing slips of varying density on biscuit fired ceramics and getting different results for each level of density. With the slip and glaze recipes she develops, she produces works with varying surface qualities.

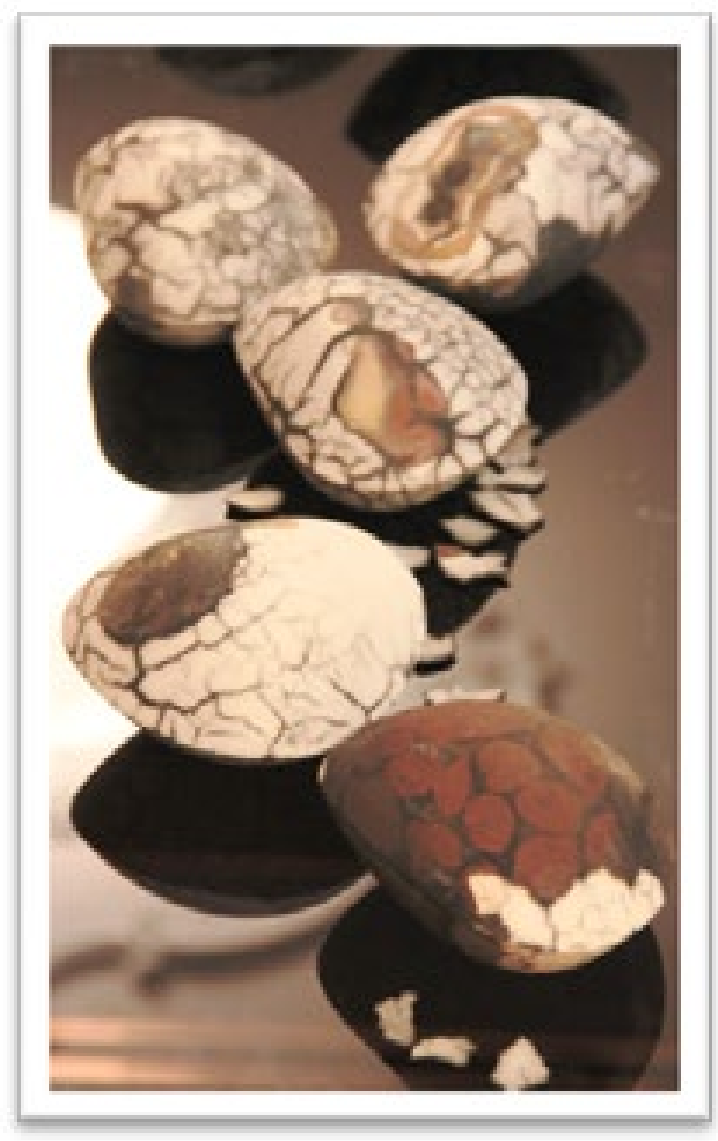

Image15: “The Hearts Believe in Itself”,Slip Casted Stoneware, Terrasigilata,Naked Raku, Each piece:13,5x10x10 cm., Installation: 30x89,5x10 cm., Photography: Şirin Koçak 


\section{CONCLUSION}

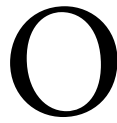

riginating in 1980s, progressing to and reaching today, 'naked raku'

firing technique has been a method used by many ceramists for the purpose of obtaining various decorative effects on ceramic surface. The search for alternatives in ceramic surfaces, emerging usage of different firing techniques and accordingly, the applications done by artists' in the light of their personal endeavours, has been the causes for this method to progress and pervade.

'Naked Raku' is the firing method where exclusively prepared slip and slip/glaze layers are applied to biscuit fired products, where these products are fired at $850-980^{\circ} \mathrm{C}$ range and at these temperatures, taken out of the oven, left to a reduction atmosphere for varying periods, dipped in water and from the surface of which the slip, slip/glaze layer is peeled like an eggshell to be taken away and where as a result, decorative effects on the surface are obtained, ranging from white to gray and gray to black according to the colour of the texture.

In 'naked raku' firing qualities of the ceramic clay, contents of the slip and the glaze, temperature of biscuit firing, how the slip is pasted, thickness of the slip and the glaze, raku firing temperature and duration, duration of reduction, type of the excelsior used in reduction, organic substances used, each of the stabilizers used after firing are factors that influence and alter the result. The influences of each of these factors are acknowledged only after long lasting experiments and applications.

This study is compiled from the Competence at Arts Report by Şirin Koçak "Sırsız Raku Araştırma ve Uygulamaları", which is aimed to constitute a source for ceramists who want to do applications concerning the subject. 


\section{REFERENCES}

\section{BOOKS}

ÇİZER, Sevim; Terra Sigillata, Birinci Basım, Tibyan Yayıncılık Basım Yayım Matbaacılık San. Tic. Ltd. Şti.,Şubat 2014,İzmir

LAZO, Eduardo, Editor, Steven Branfman, Kate andWillJacobson, WallyAsselberghs, Lindaand Charlie Riggs, Amber Aquirre, Dana BilelloBarrow, David Lazo, Contributors; Naked Raku and Related Bare Clay Techniques, TheAmericanCeramicSociety, USA, 2012

ŞÖLENAY, Emel; Seramik Sanat Eğitiminde Sırlama ve Pişirme Yöntemleri El Kitabı, Murat Kitabevi,2000, İstanbul

KOÇAK, Şirin; "Sırsız Raku Araştırma ve Uygulamaları" ( Naked Raku Researches and Applications), Yayımlanmamış Sanatta Yeterlik Eseri Çalışması Raporu, Dokuz Eylül Üniversitesi Güzel Sanatlar Enstitüsü Seramik ve Cam Ana Sanat Dalı, İzmir, 2014

WEB

http://www.ceramicsnow.org/davidroberts

http://www.davidroberts-ceramics.com/technicalnotes.php 